\title{
Insider Trading in Large Canadian Banks
}

\author{
Hamadou Boubacar (Corresponding author) \\ Faculty of Business Administration, University of Moncton \\ 41, avenue Antonine-Maillet, Moncton, E1A 3E9, N.-B, Canada \\ Tel: 1-506-858-4557 E-mail: hamadou.boubacar@umoncton.ca
}

Tania Morris

Faculty of Business Administration, University of Moncton

41, avenue Antonine-Maillet, Moncton, E1A 3E9, N.-B, Canada

Tel: 1-506-858-4218Ｅ-mail: tania.morris@umoncton.ca

Received: June 13, 2011

Accepted: July 5, 2011

Published: November 1, 2011

doi:10.5539/ijef.v3n6p25

URL: http://dx.doi.org/10.5539/ijef.v3n6p25

The research is financed by the chair Jeanne et J.-Louis-Lévesque in financial studies. The chair is located at the faculty of business administration of the University of Moncton. Its role is to realize researches on the current problems in finance topic and, to develop and promote various activities connected to the financial field for the French-speaking and Acadian populations of the Canadian Atlantic Provinces.

\begin{abstract}
The aim of this study is, on the one hand, to determine if directors of large Canadian banks obtained abnormal returns by buying or selling their own bank stocks and, on the other hand, to evaluate market reaction when these transactions were made public. Our results show that markets reacted more to the selling of stocks as opposed to the buying of stocks. They also show that directors of large Canadian banks did not seem to profit excessively by buying stocks and that they had sold their stocks strategically as a result of higher value on stock exchanges.
\end{abstract}

Keywords: Insider trading, Canadian banks, Abnormal return, Financial market reaction

\section{Introduction}

In Canada, insider trading refers to the purchase or the selling of stock of a firm by an «insider », that is, a person who has knowledge of confidential information pertaining to the firm that will probably have a real influence on the value of the stock, while other shareholders and the public in general do not possess such information (Note 1). By itself, insider trading is not illegal. In most countries where there are laws with respect to insider trading, the latter can sell or buy shares of firms with which they have dealings on condition that they do not possess privileged information on the firms themselves. Conversely, if the insider possesses confidential information regarding a firm and such information can be used for personal gain in buying or selling company shares, he must refrain from any such trades. The proper regulation of insider trading is therefore necessary for many reasons since it represents a major factor in the development of countries [La Porta et al. (2000)]. Here we note simply that in the absence of such regulation, confidential information held by insiders would allow them to gain financially at the expense of other shareholders. Consequently, the reputation of the firm could be tarnished or even worse and the very confidence of stock markets could be placed in doubt notably because of possible liquidity problems [Fishe and Robe (2004)].

The interest of our research is due to the fact that it relates to the Canadian banks. Banks are not only commercial enterprises in themselves, but of specific interest due to the nature of their activities and the important role they play in Canadian economics. Canadian banks drive the Toronto Stocks Exchange (TSX) to 2-year high. The TSX index climbed to its highest level in two years, as a solid banking sector and rising commodity prices saw investors push the TSX through a key resistance level. According to this theory "too big to fail", certain financial institutions like banks are so large and so interconnected that their failure will be disastrous to an economy. All this, to underline the weight of the six Canadian large banks in the economy and their role of first rank to the Toronto Stock Exchange where they account for $25 \%$ of the TSX index. The insiders trading in Canadian banks were recently very important, as the 
following example shows it. Thus, the Canadian journal « La Presse Affaires » [Munger (2010)] (Note 2) reports that the directors of the Bank of Montreal (BMO) have recently sold thousand's of common stocks, netting them substantial revenue. As well, a director sold 10000 shares at a unit price of $\$ 58.95$ on March 5, 2010. This transaction netted gross revenue of $\$ 589500$. Another manager of BMO liquidated 12400 shares on the same date. By selling at a price slightly higher than $\$ 59.31$ per share, he received $\$ 735565$ in exchange for his stocks. At the same time, an executive vice-president made the largest transaction by selling 20000 shares at a per unit price of $\$ 60.82$. This generated gross revenue of about $1.22 \mathrm{M} \$$. After these transactions, the BMO stock price was volatile on the Toronto Stock Exchange. The stock peaked at \$65.41 on April 26, 2010 at a level not seen since the end of summer 2007.

The aim of this research is to study the behaviour of the board-members of the six large Canadian banks (Note 3 ), as they trade the stocks held in the firms they direct and evaluating the market perception relative to the stock transactions conducted by the latter. It is a subject that is pertinent to researchers and investors insofar as any gain attributed to a financial transaction by one party, there is consequently a loss attributed to another party. Such a loss is particularly unacceptable if the gain is realized by an insider trade due to a privileged position with the firm and thus detrimental to all other uninformed shareholders. Let us emphasize as well that it is the directors who have the ultimate responsibility to supervise the direction and management of public firms. At the same time, these directors are often remunerated by stock-options and hence possess an important number of stocks in the banks they direct. The questions at the heart of this debate are: 1) Did the directors of large Canadian banks earned abnormal returns by buying or selling their own bank stocks? 2) How does the Canadian financial market react to these transactions once made public? The subjects like insider trading, abnormal returns and the effect of insider trading on the stock market have attracted great attentions from both academic researchers and the investing public. These subjects are so interesting because insiders who possess inside information about their firms may be motivated to take advantage of it through trading on their firms' stocks, but are prohibited by laws from trading based on non-public material information.

The rest of the paper is structured as follows: section 2 reviews some of the literature on the topic and presents the hypotheses. Section 3 presents the data and describes the methodology of the study. Section 4 shows the results, whilst section 5 focuses on a summary and conclusions of the study.

\section{Literature Review and Hypotheses}

\subsection{Insider trading and abnormal security returns}

Many studies (e.g.; Jaffe, 1974; Seyhun, 1986; Ke et al., 2003; Dymke and Walter, 2008; Aktas et al., 2008; Kallunki et al., 2009; Betzer and Theissein, 2009; Betzer and Theissein, 2010; Kolasinski and Li, 2010) conclude that insiders can earn abnormal profits through trading stocks of their own firms. Apart from investigating the abnormal profits of the stock price around insider transactions, research efforts also focus on whether financial markets react to insider trading (e.g.; Seyhun, 1986; Datta and Iskandar-Datta, 1996; Fidrmuc et al., 2006; Aktas et al., 2008; Ma et al., 2009). However, to the best of our knowledge, no study specifically identified insider trading in the banking sector. We focused our literature review on these two major strands.

A strand of studies focuses on the abnormal returns gained by insiders. Indeed, according to Dymke and Walter (2008), in Germany, corporate insiders are able to identify profitable investment situations and thus realize substantial profits by trading their company's stocks. For example, considering 20-day period subsequent to the trading day, stocks traded by insiders are associated with significant cumulative abnormal returns: $4.38 \%$ for purchases and $-1.47 \%$ for sales. In particular, executive managers earned a profit of more than $4 \%$ on the buy side with those transactions not succeeded by an ad-hoc news release. Compared to the respective numbers for directors $(1.81 \%)$ and other insiders (2.12\%), executive managers yield high profits. Using event-study methodology, Betzer and Theissen $(2009 ; 2010)$ found that in Germany, insider trading affects share prices significantly. In the 20 days after the trade, market-model adjusted cumulative abnormal returns amounted to $3.60 \%$ after purchases and $-3.54 \%$ after sales. Similar results were obtained in the U.K. by Fidrmuc et al. (2006). Using a data set of 297 firms, 1723 insiders and 5227 insider transactions comprising 2579 sell transactions and 2648 buy transactions, Kallunki et al. (2009) found that greater future abnormal returns follow insider buying than selling. Insider purchases are associated with positive returns, but sales are not associated with negative returns. Studying 346120 insider transactions for 6 925 firms, Kolasinski and Li (2010) assert that insiders trade as if they exploit market underreaction to earnings news, buying (selling) after good (bad) earnings announcements when the price reaction to the announcement is low (high). They also find that insider trades attributable to public information about earnings and the price reaction generate abnormal returns. Finally, we can mention that, with 309190 trades by insiders identified as directors or officers, Ke et al. (2003) conclude that insider stock sales are greater for growth firms, before a longer period of declining earnings, and when the earnings decline at the break is greater. We thus formulate the following 
hypothesis:

H1: the board-members of Canadian banks earned abnormal profits when they purchase or sell the stocks of their own banks.

\subsection{Insider trading and financial market reaction}

Another strand of literature questioned about the financial market reaction to the insider trading. Hence, using 59 244 aggregated daily insider trades on 2110 companies subject to between January 1995 and the end of September 1999, Aktas et al. (2008) found that, even though financial markets do not respond strongly in terms of abnormal returns to insider trading activities, the significant change in price sensitivity to relative order imbalance due to abnormal insider trades reveals that price discovery is hastened on insider trading days. Similar results by Datta and Iskandar-Datta (1996) report significant positive price reactions for convertible and straight bonds in response to the Wall Street Journal's Insider Trading Spotlight publication of insider buy transactions and significant negative reactions for insider sell transactions. Fidrmuc et al. (2006) investigate the market's reaction to U.K. insider transactions and analyze whether the reaction depends on the firm's ownership. Their results strongly support that there is a strong positive market reaction to directors' purchases given their high informational content. For example, for large trades, the two-day CAAR based on the announcement day and the following day from the market model is $3.1 \%$ and strongly significantly different from zero regardless of the test statistic used. Conversely, the CAAR is significantly negative $(-1.27 \%)$ over the 20 days prior to purchases. This suggests that directors are able to time their purchases. With a sample of 414 firms, of which 163 are insider purchases and 251 are insider sales, Ma et al. (2009) indicate that the market tends to under-react to the insider trading information and insiders tend to be information-motivated traders. Thus, ideally one would wish to test the following hypotheses:

H2a: the purchase by the directors of Canadian bank affects positively the financial market.

H2b: the sale by the directors of Canadian bank affects negatively the financial market.

\section{Data and Methodology}

\subsection{Data and Description}

We obtain data from the System for Electronic Disclosure by Insiders, known as SEDI, which is the Canadian electronic system for filing and publicly disseminating insider trading reports. SEDI is available to anyone with Internet access and lets insiders, agents and issuers file statutory reports on a 24-hour basis. Reports are available to the public within five minutes of being filed on the system. For each insider transaction, SEDI provides the name of the company, the stock exchange symbol, the name of the trader, his relationship with the company, the transaction ID number, the transaction date, the date registered with SEDI, the name of the share, the nature of the transaction, and the number of shares purchased or sold with their price. Consequently, we download all the transactions (purchases and sales) of stocks conducted by the directors of the six large Canadian banks (Bank of Nova Scotia, Canadian Imperial Bank of Commerce, Bank of Montreal, National Bank, Royal Bank of Canada and Toronto-Dominion Bank) between 2006 and 2008. Thus, our sample consists of 6 large Canadian banks, of which 266 are insider purchases (insider purchase sample) and 61 are insider sales (insider sale sample). Finally, we can mention that the data on market returns and the data on daily stock returns that surround the trading day and the reporting day are obtained from Canadian Financial Markets Research Centre (CFMRC) database.

Table 1 shows the generation of the number and the value of the transactions (purchases and sales) conducted by the board-members of the six large Canadian banks between 2006 and 2008. We can note that the number of purchases account for about $81 \%$ of all insider trades (266 out of 327), but in value sales represent about $86 \%$ of the total value of all trades. In particular, the directors of the National Bank rank first with regards to the purchases. Hence, they realized 60 transactions for a total value of $\$ 511780$ in 2006, 56 transactions for a total value of $\$ 463682$ in 2007 , and 58 transactions for a total value of $\$ 618419$ in 2008. However, if we instead privilege the value of the transactions, we note that the merit for accomplishment in 2006 (\$4 007584 in 8 transactions) and 2007 (\$1 972350 in one transaction) is awarded to the directors of Toronto-Dominion Bank. If the directors of this bank did not realize any transactions in 2008, directors of the Bank of Nova Scotia purchased shares of their bank for a value of $\$ 1246821$. As for sell orders, we note that the directors of the National Bank and of the Royal Bank of Canada executed substantial stock trades, particularly in 2006 and 2007. While directors of the National Bank transacted for \$9 235678 in 2006, \$7 385393 in 2007, and \$14 628318 in 2008, directors of the Royal Bank of Canada obtained $\$ 20487313$ and \$19 998336 respectively in 2006 and 2007.

\subsection{Methodology}

We first computed the abnormal returns for the dates surrounding the transactions (purchases and sales) of stock and the reporting days in SEDI. In order to do this, the daily returns of shares are compared to their normal returns; i.e., 
the theoretical returns for the same day if there had been no transactions realized on the stock market by the same bank directors, taking into account the economic conditions that prevailed on the market on that date. In this study, we measure abnormal returns (returns that deviate from the normal return), subsequent to the banks directors trading day by applying event-study methodology outlined by Brown and Weinstein (1985), and MacKinley (1997). According to the authors, this methodology requires defining "event windows" which indicate the number of days before and after the announcement date over which the abnormal returns is accumulated. An event window is typically denoted $[-a,+b]$, where " $a$ " is the number of days before the announcement day and " $b$ " is the number of days after the announcement day, and where the announcement day is typically denoted as "day 0". In our study, we consider two announcement days: the transaction day and the reporting day. Indeed, the estimation window, which must be neutral regarding events is $[-250,-220]$, the event window for the transaction date is $[-30,+30]$ to evaluate the abnormal returns and the event window for the reporting day is $[-10,+10]$ to evaluate the market reaction. A longer event window for the transaction day is needed to observe the evolution on the stock market price before and after the transaction.

In order to evaluate the event's impact on stock return, we need a measure of the abnormal return around the event period. As define by MacKinlay (1997), the abnormal return for firm $i$ and event date $\tau$ is the actual return of the security $\left[\mathrm{R}_{\mathrm{i}, \tau}\right]$ minus a measure of the normal return that would have occur, without the event of an insider trading $\left[\mathrm{E}\left(R_{i \tau} \mid X_{\tau}\right)\right]$. The abnormal return is thus:

$\mathrm{AR}_{\mathrm{i}, \tau}=\mathrm{R}_{\mathrm{i}, \tau}-\mathrm{E}\left(R_{i \tau} \mid X_{\tau}\right)$

In this research we used to market model to measure the normal return. As stated by MacKinlay (1997), "The market model represents a potential improvement over the constant mean return model. By removing the portion of the return that is related to variation in the market's return, the variance of the abnormal return is reduces. This in turn can lead to increased ability to detect event effects". We thus followed the widely used event-study methodology (Brown and Weinstein, 1985 and Mackinlay, 1997, Chance \& Al, 2000, Yermack, 1997, Fidrmuc et al., 2006) in which the abnormal return measure is:

$\mathrm{AR}_{\mathrm{i}, \tau}=\mathrm{R}_{\mathrm{i}, \tau}-\left(\alpha_{\mathrm{i}}+\beta_{\mathrm{i}} \mathrm{R}_{\mathrm{m}, \tau}\right)$

Where $R_{i}, \tau=$ the returns of security, $i$, at time $\tau ; R_{m, \tau}=$ returns of the market portfolio at time $(\tau), \alpha_{i}$ and $\beta_{i}$ are the parameters of the market model. We used the TSX composite index to estimate the return of the market portfolio.

Before the statistical analysis, it important to group the stocks according to the calendar of the event, in order to calculate the average of security i's daily abnormal returns $\left(\mathrm{AAR}_{\tau}\right)$ and the cumulative average abnormal return $\left[\mathrm{CAAR}_{\mathrm{i}}\left(\tau_{1}, \tau_{2}\right)\right]$ of the sample. Indeed:

- the average abnormal return is measured as follows:

$\operatorname{AAR}_{\tau}=\frac{1}{N} \sum_{\tau=1}^{N} \operatorname{AR}_{i, \tau}$

and for large event window, its variance is

$\operatorname{VAR}\left(\operatorname{AAR}_{\tau}\right)=\frac{1}{\mathrm{~N}^{2}} \sum_{\mathrm{i}=1}^{\mathrm{N}} \sigma_{\varepsilon_{\mathrm{i}}}^{2}$

- the CAAR from $\tau_{1}$ to $\tau_{2}$, the sum of the included abnormal returns is calculated as follows:

$\operatorname{CAAR}_{\mathrm{i}}\left(\tau_{1}, \tau_{2}\right)=\sum_{\tau=\tau_{1}}^{\tau_{2}} \operatorname{AR}_{\mathrm{i}, \tau}$

and for large estimation window, the variance of $\mathrm{CAAR}_{\mathrm{i}}$ is

$\sigma_{i}^{2}\left(\tau_{1}, \tau_{2}\right)=\left(\tau_{2}-\tau_{1}+1\right) \sigma_{\epsilon_{i}}^{2}$

The following tests of the significance of the AAR and the CAAR are done:

- to test if the AAR is statistically different from zero on the day [0], we calculated the following t-statistic

$\mathrm{AAR}_{\tau} / \hat{\sigma}\left(\mathrm{AAR}_{\tau}\right)$

- to test if the $\operatorname{CAAR}_{\tau}^{\tau+\mathrm{n}}$ is statistically different from zero, we calculated the following t-statistic 


\section{$\operatorname{CAAR}_{\tau}^{\tau+\mathrm{n}} / \hat{\sigma}\left(\operatorname{CAAR}_{\tau}^{\tau+\mathrm{n}}\right)$}

In order to test our hypothesis according to which bank directors obtained abnormal returns by trading on the stock market, we test two null hypotheses:

- for the first one on the average abnormal return, we use the following t-statistic

$$
\frac{\mathrm{AAR}_{\text {purchase }}-\mathrm{AAR}_{\text {sale }}}{\sqrt{\operatorname{VAR}\left(\mathrm{AAR}_{\text {purchase }}\right)}+\operatorname{VAR}\left(\mathrm{AAR}_{\text {sale }}\right)} \sim \mathrm{N}(0,1)
$$

- and for the second one on the cumulative average abnormal return, we use the following t-statistic

$$
\frac{\text { CAAR }_{\text {purchase }}-\mathrm{CAAR}_{\text {sale }}}{\sqrt{\operatorname{VAR}\left(\mathrm{CAAR}_{\text {purchase }}\right)}+\operatorname{VAR}\left(\mathrm{CAAR}_{\text {sale }}\right)} \sim \mathrm{N}(0,1)
$$

\section{Results}

\subsection{Security trading by directors of Canadian banks and abnormal security returns}

Figure la presents the cumulative average abnormal return (CAAR) starting on the 10th day preceding the announcement until the 10th day following the announcement of security transactions (purchase and sale), by the Canadian banks board-members. This figure shows, on the one hand, that directors did not seem to get richer by buying stock, and on the other hand, it displays that the directors obtain abnormal returns by selling their securities.

These results are confirmed in Table 2 that presents the tests on the average abnormal return and the CAAR. Let us note that Part A of Table 2 indicates that we obtain a negative and significant CAAR following the purchase transactions by the board-members of the banks (CAAR $[0 ; 3]$, CAAR $[0 ; 5]$ and CAAR $[0 ; 10]$ ). In the same way, our results show a negative and significant CAR following the sales (CAAR [0; 3], CAAR [0; 5] and CAAR [0; 10]). Some of our findings corroborate previous and recent results. For example, Dymke and Walter (2008) obtained a CAAR $[0 ; 10]$ of $-0.84 \%$ while for this event period we obtain a CAAR of $-2.20 \%$. In addition, previous studies such as those of Lakonishok and Lee (2001) and Dymke and Walter (2008) confirm that the purchases transactions, contrary to the sales transactions, allow insiders to make richer. Indeed, contrary to purchases transactions, sales transactions can be conducted for motivations other than seeking profit. However, the statistical tests of our study show that the sales provide an abnormal return over 10 days that is significantly higher than the abnormal return obtained on the purchases (see Part A of Table 2 where the CAAR $[0 ; 10]$ is $-1.66 \%$ significantly lower than the purchase operations). This seems to indicate that it is the market tendency that allows the insiders to be the first to profit on purchase or sale operations. In a bull market, purchases transactions are more profitable while in a bear market, sales transactions are more profitable.

\subsection{Security trading by directors of Canadian banks and market reaction}

In Figure $1 b$, we observe a decrease trend in the CAAR from the day 0 to the day +4 for the purchase. Our results indicate a negative abnormal return on the deposit day and a tendency to decrease on the following days of the deposit of a sale transaction by the directors, reaching an average abnormal return of $-1.06 \%$ on day +10 . However, the results of the tests do not seem conclusive for purchases transactions. Part $B$ of Table 2 indicates divergent sign for the CAAR for the windows $[0 ; 3],[0 ; 5]$ and $[0 ; 10]$ and that the tests are of little significance. Indeed, unlike Fidrmuc et al. (2006), we do not obtain any support of our hypothesis. Nevertheless, we observe significant CAARs of $-0.92 \%,-2.10 \%$ and $-0.65 \%$ for the periods $[0 ; 3],[0 ; 5]$ and $[0 ; 10]$ respectively. These last results are in accordance with some conclusions drawn by Seyhun (1986).

In Part B of Table 2, we notice a negative and significant average abnormal return on the deposit day of a purchase transaction and for the preceding days, namely, [0] and [-1]. The tests also show a positive and significant average abnormal return for the days, $[+1]$ and $[+2]$ following the deposit day. Thus, the Canadian financial market reacts positively to purchase announcements by the board-members, but only for days $[+1]$ and $[+2]$ with a significant average abnormal return of $0.33 \%$ and $0.30 \%$ respectively. The results therefore confirm our research hypothesis for days [+1] and [+2], but it is difficult to explain the absence of a reaction on day zero. This absence of a reaction is perhaps due to the low value of purchases transactions in our sample and to the fact that, the market can interpret difficultly, the buying operations in a bear market. It may be also due to the fact that the market receives the information only on the day [+1]. Moreover, the statistical tests in Table 2 show a significant average abnormal return of $-0.60 \%$ on the deposit day of a sales transaction. This negative average abnormal return persists for a 
period of at least 10 days. In effect, the negative CAAR is significant for the sub-periods of three days, five days, and ten days following the deposit of a sale operation. Hence, the market seems to react negatively to announcements of sell orders by board-members. Finally, it also appears that the CAAR following the deposit of the sales transactions is lower than those following the deposit of purchase operations. In effect, we obtain CAARs of $1.27 \%, 1.66 \%$ and $0.72 \%$ that are significantly lower for sales transactions than for the purchase operations for the periods $[0 ; 3],[0,5]$, and $[0 ; 10]$ respectively. These results indicate that the market receives the information from stock exchange operations conducted by the board-members in the period 2006 to 2008 . The market reacts more to the sales operations than to the purchase transactions [Aktas et al. (2008)].

\section{Summary and Conclusions}

\subsection{Summary}

In this research we examined if the board-members of the six large Canadian banks earned abnormal return and consequently if the market reacts to this. In order to proceed, we used a sample composed of all the purchases and the sales of stocks conducted by the directors of these banks during the 2006-2008 periods, for a total of 266 purchases and 61 sales of stocks. We also collected data relative to market returns and to daily stock returns surrounding the transaction day and the deposit day, from the TSX-CFMRC database.

\subsection{Conclusions and Managerial Implications}

Our results reveal that directors do not seem to profit in buying stocks in their banks. Even more, we find a negative CAAR after selling securities when the date of the sale is preceded by a positive CAAR of $1.39 \%$ on day [-2] and $1.16 \%$ on day [-1]. An analysis shows that directors of the six Canadian banks strategically sold their shares following an increase in the market price and that their announcement is followed by a decrease in market price. These results allow us to conclude that the market viewed such stock transactions conducted by the board-members as a signal. In effect, the Canadian stock market reacted more following the sales operations rather than the purchases operations. The results also indicate that it is the market tendency that allows the insiders to be the first to profit on purchase or sale operations. In a bull market, purchases transactions are more profitable while in a bear market, sales transactions are more profitable.

Like all research studies, ours' contains certain limitations. As for the size of the sample, we only used 61 sales transactions, which is relatively few when compared to the purchases transactions realized by directors of Canadian banks and could affect the scope or the range of our results. Consequently, there is no proof that these results can be generalized. Hence, to compensate for these insufficiencies, we envisage in a future study to include all Canadian financial institutions (banks and insurance companies) and to enlarge the base of insider trading by including other categories of insiders (e.g.: senior management staff such as the V.P. finance, and persons, including firms, that control more than $10 \%$ of company voting stock, even including members of their family).

\section{References}

Aktas, N. de Bodt, E. Van Oppens, H. (2008). Legal insider trading and market efficiency. Journal of Banking \& Finance. 32 (7), 1379-1392, http://dx.doi.org/10.1016/j.jbankfin.2007.11.003

Betzer, A. Theissen, E. (2009). Insider Trading and Corporate Governance: The Case of Germany. European Financial Management. 15(2), 402-429, http://dx.doi.org/10.1111/j.1468-036X.2007.00422.x

Betzer, A. Theissen, E. (2010). Sooner or Later: An Analysis of the Delay in Insider Trading Reporting. Journal of Business Finance and Accounting. 37(1-2), 130-147, http://dx.doi.org/10.1111/j.1468-5957.2009.02173.x

Brown, S. Weinstein, M.I. (1985). Derived Factors in Event Studies. Journal of Financial Economics. 14(3), 491-495, http://dx.doi.org/10.1016/0304-405X(85)90010-8

Chance, D.M. Kumr, R. Todd, R.B. (2000). The "repricing" of executive stock options. Journal of Financial Economics, 57(1), 129-154, http://dx.doi.org/10.1016/S0304-405X(00)00053-2

Datta, S. Iskandar-Datta, M.E. (1996). Does insider trading have information content for the bond market? Journal of Banking \& Finance. 20(3), 555-575, http://dx.doi.org/10.1016/0378-4266(95)00005-4

Dymke, B.M. Walter, A. (2008). Insider Trading in Germany - Do Corporate Insiders Exploit Inside Information? Official Open Access Journal of VHB. 1(2), 188-205.

Fidrmuc, J.P. Goergen, M. Renneboog, L. (2006). Insider Trading, News Releases, and Ownership Concentration. Journal of Finance. 61(6), 2931-2973, http://dx.doi.org/10.1111/j.1540-6261.2006.01008.x

Fishe, R.P.H. Robe, M.A. (2004). The Impact of Illegal Insider Trading in Dealer and Specialist markets: Evidence from a Natural Experiment. Journal of Financial Economics. 71(3), 461-488, 
http://dx.doi.org/10.1016/S0304-405X(03)00188-0

Jaffe, J.F. (1974). Special Information and Insider Trading. Journal of Business. 47(3), 410-428, http://dx.doi.org/10.1086/295655

Kallunki, J.-P. Nilsson, H. Hellstrom, J. (2009). Why do insiders trade? Evidence based on unique data on Swedish insiders. Journal of Accounting and Economics. 48 (1), 37-53, http://dx.doi.org/10.1016/j.jacceco.2009.06.002

Ke, B. Huddart, S. Petroni, K. (2003). What Insiders Know About Future Earnings and How They Use It: Evidence from insider trades. Journal of Accounting and Economics. 35 (3), 315-346, http://dx.doi.org/10.1016/S0165-4101(03)00036-3

Kolasinski, A. Li, X. (2010). Are corporate managers savvy about their stock price? Evidence from insider trading after earnings announcements. Journal of Accounting and Public Policy. 29 (1), 27-44, http://dx.doi.org/10.1016/j.jaccpubpol.2009.10.004

Lakonishok, J. Lee, I. (2001). Are Insiders' Trades Informative? Review of Financial Studies. 14 (1), 79-111, http://dx.doi.org/10.1093/rfs/14.1.79

La Porta, R. Lopez-De-Silanes, F. Shleifer, A. Vishny, R.W. (2000). Investor Protection and Corporate Government. Journal of Financial Economics. 58 (1-2), 3-29, http://dx.doi.org/10.1016/S0304-405X(00)00065-9

Ma, Y. Sun, H-L. Tang, A.P. (2009). Do insiders have inside tracks: An examination of Wall Street Journal's Inside Track columns? International Review of Economics \& Finance. 18(3),520-530, http://dx.doi.org/10.1016/j.iref.2008.09.001

MacKinlay, A.C. (1997). Event Studies in Economics and Finance. Journal of Economic Literature. 35(1), 13-39.

Seyhun, H.N. (1986). Insiders Profits, Costs of Trading, and Market Efficiency. Journal of Financial Economics. 16(2), 189-212, http://dx.doi.org/10.1016/0304-405X(86)90060-7

Yermack, D. (1997). Good Timing: CEO Stock Option Award and Compagny News Announcements. The Journal of Finance, 52(2), 449-476, http://dx.doi.org/10.2307/2329486

Notes

Note 1. The definition of insider trading is quite broad. It is comprised of the firm (including moral persons), administrators or directors of the firm, individual shareholders who hold more than $10 \%$ of company stock, employees of the firm and all persons that exert or who intend to exert a commercial or professional activity with the firm or for their own business practice, including their respective employees.

Note 2. See "Argent" - TVA on May 10, 2010.

Note 3. They are the Bank of Nova Scotia, Canadian Imperial Bank of Commerce, Bank of Montreal, National Bank, Royal Bank of Canada, and Toronto-Dominion Bank. 
Table 1. Description of Sample

\begin{tabular}{|c|c|c|c|c|c|c|}
\hline & \multicolumn{2}{|c|}{2006} & \multicolumn{2}{|c|}{2007} & \multicolumn{2}{|c|}{2008} \\
\hline & $\begin{array}{l}\text { Number of } \\
\text { transactions }\end{array}$ & $\begin{array}{c}\text { Amount } \\
(\$)\end{array}$ & $\begin{array}{l}\text { Number of } \\
\text { transactions }\end{array}$ & $\begin{array}{c}\text { Amount } \\
\mathbf{( \$ )}\end{array}$ & $\begin{array}{c}\text { Number of } \\
\text { transactions }\end{array}$ & $\begin{array}{c}\text { Amount } \\
\text { (\$) }\end{array}$ \\
\hline \multicolumn{7}{|l|}{ Part A: Purchase } \\
\hline Bank of Nova Scotia & 1 & 8037 & 13 & 1748618 & 7 & 1246821 \\
\hline Canadian Imperial Bank of Commerce & 2 & 58104 & 6 & 94157 & 5 & 56530 \\
\hline Bank of Montreal & 2 & 260708 & 2 & 380777 & 12 & 674274 \\
\hline National Bank & 60 & 511780 & 56 & 463682 & 58 & 618419 \\
\hline Royal Bank of Canada & 11 & 611361 & 5 & 429403 & 17 & 813400 \\
\hline Toronto-Dominion Bank & 8 & 4007584 & 1 & 1972350 & 0 & 0 \\
\hline Total & & 5457572 & & 5088937 & & 3409445 \\
\hline \multicolumn{7}{|l|}{ Part B: Sales } \\
\hline Bank of Nova Scotia & 2 & 5928774 & 4 & 5139785 & 0 & 0 \\
\hline Canadian Imperial Bank of Commerce & 1 & 73110 & 0 & 0 & 0 & 0 \\
\hline Bank of Montreal & 1 & 68980 & 0 & 0 & 7 & 364238 \\
\hline National Bank & 6 & 9235678 & 4 & 7385393 & 9 & 14628318 \\
\hline Royal Bank of Canada & 11 & 20487313 & 10 & 19998336 & 4 & 445733 \\
\hline Toronto-Dominion Bank & 2 & 255597 & 0 & 0 & 0 & 0 \\
\hline Total & & 36049435 & & 32523514 & & 1543289 \\
\hline
\end{tabular}

This table displays the number and the value of transactions (buy and sell sides) conducted by the directors of the six large Canadian banks during the period 2006 to 2008 .

Table 2. Summary statistics on board-members transactions

\begin{tabular}{|c|c|c|c|}
\hline Trading Day & Purchase $\quad(N=266)$ & Sales $(\mathrm{N}=61)$ & Difference \\
\hline \multicolumn{3}{|c|}{ Part A: Transaction Date } & \\
\hline CAAR $[-30 ;-1]$ & $0.06 \%$ & $4.41 \%{ }^{* * *}$ & $4.35 \%{ }^{* * *}$ \\
\hline CAAR $[-20 ;-1]$ & $0.28 \%$ & $3.53 \%{ }^{* * *}$ & $3.25 \%{ }^{* * *}$ \\
\hline CAAR $[-10 ;-1]$ & $-0.07 \%$ & $1.16 \%{ }^{* *}$ & $1.23 \%^{* *}$ \\
\hline CAAR $[0 ; 3]$ & $-0.54 \%^{* * *}$ & $-0.95 \%{ }^{* * *}$ & $-0.41 \%$ \\
\hline CAAR $[0 ; 5]$ & $-0.76 \%{ }^{* * *}$ & $-0.64 \%^{* *}$ & $0.12 \%$ \\
\hline CAAR $[0 ; 10]$ & $-0.54 \%{ }^{* *}$ & $-2.20 \%{ }^{* * *}$ & $-1.66 \%{ }^{* * *}$ \\
\hline \multicolumn{3}{|c|}{ Part B: Deposit Day } & \\
\hline AAR [-1] & $-0.43 \%{ }^{* * *}$ & $-0.22 \%$ & $0.21 \%$ \\
\hline AAR [0] & $-0.45 \%{ }^{* * *}$ & $-0.60 \%{ }^{* * *}$ & $-0.15 \%$ \\
\hline AAR [1] & $0.33 \%{ }^{* * *}$ & $0.09 \%$ & $-0.24 \%$ \\
\hline AAR [2] & $0.30 \%{ }^{* * *}$ & $0.28 \%$ & $-0.02 \%$ \\
\hline AAR [3] & $-0.11 \%$ & $-0.42 \%^{*}$ & $-0.31 \%$ \\
\hline CAAR $[0 ; 3]$ & $0.35 \%{ }^{*}$ & $-0.92 \%^{* * *}$ & $-1.27 \%^{* * *}$ \\
\hline CAAR $[0 ; 5]$ & $-0.44 \%^{*}$ & $-2.10 \%{ }^{* * *}$ & $-1.66 \%{ }^{* * *}$ \\
\hline CAAR $[0 ; 10]$ & $0.07 \%$ & $-0.65 \%{ }^{* *}$ & $-0.72 \%^{* *}$ \\
\hline
\end{tabular}

$* * * \mathrm{p} \leq 0.01 ; * * \mathrm{p} \leq 0.05 ; * \mathrm{p} \leq 0.1$

Table 2 presents the standard parametric tests on AAR and CAAR in order to verify if the abnormal returns observed surrounding the transaction date (Part A) and the deposit date (Part B) are significantly different from zero. The tests are conducted on the AAR on day zero, certain days surrounding day zero, and on the CAAR for certain sub-periods surrounding the event date. The first column shows the market day relative to the event date (transaction and deposit). The second and third columns show the AAR and CAAR for the periods identified in the first column. Finally, the fourth column shows the difference between the abnormal return obtained during a sell operation and that obtained during a buy operation. 
a) Transaction Date

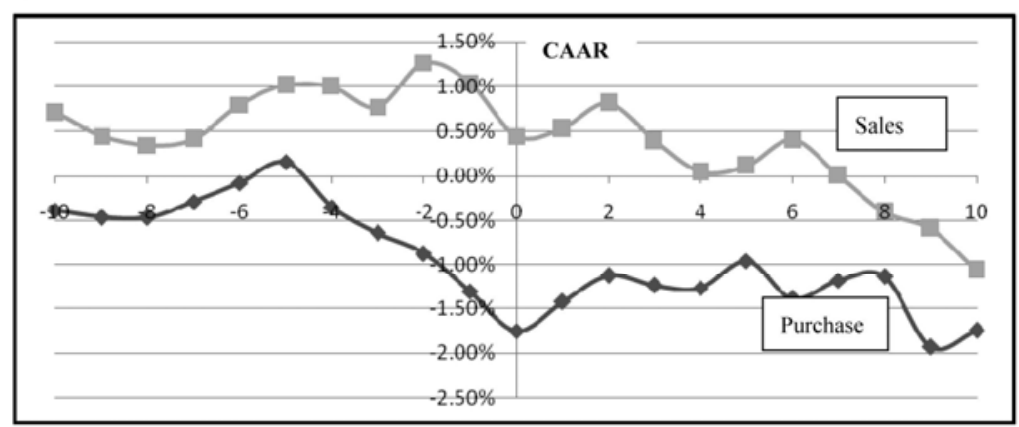

b) Deposit Date

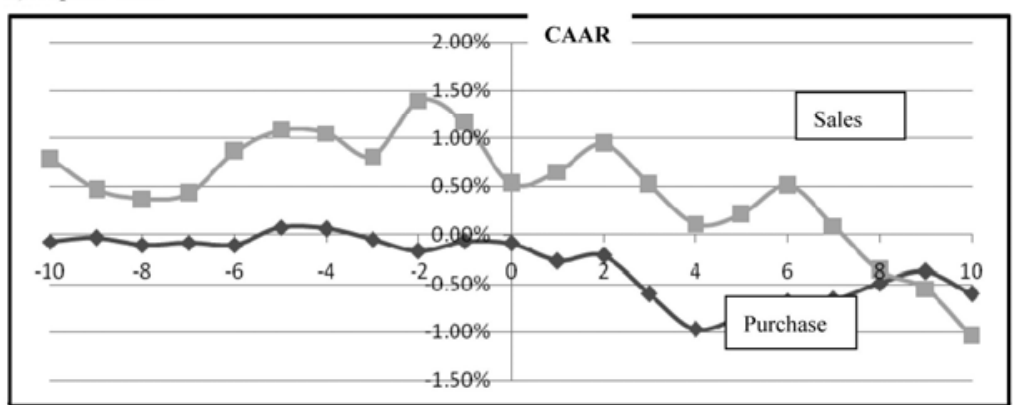

Figure 1. CAAR surrounding the Transaction date and Deposit date 